\title{
Experience of health professionals in care of the homeless population with tuberculosis*
}

\author{
Experiência dos profissionais de saúde no cuidado da \\ pessoa com tuberculose em situação de rua \\ Experiencia de los profesionales sanitarios en el cuidado a la \\ persona con tuberculosis en situación de calle
}

Tatiana Ferraz de Araújo Alecrim, Fernando Mitano ${ }^{2,3}$, Amanda Alessandra dos Reis ${ }^{1}$, Cristine Moraes Roos ${ }^{4}$, Pedro Fredemir Palha ${ }^{5}$, Simone Teresinha Protti-Zanatta ${ }^{6}$

How to cite this article:

Alecrim TFA, Mitano F, Reis AA, Roos CM, Palha PF, Protti-Zatnatta ST. Experience of health professionals in care of the homeless population with tuberculosis. Rev Esc Enferm USP. 2016;50(5):808-815. DOI: http://dx.doi.org/10.1590/S0080-623420160000600014

*Extracted from the dissertation: "A rua que acolhe, a rua que cura: equipe de consultório na rua como estratégia para atenção à pessoa com tuberculose", Programa de Pós-Graduação em Enfermagem, Universidade Federal de São Carlos, 2015. 1 Universidade Federal de São Carlos, Programa de Pós-Graduação em Enfermagem, São Carlos, SP, Brazil.

${ }^{2}$ Universidade de São Paulo, Escola de Enfermagem de Ribeirão, Programa de Pós-Graduação Enfermagem em Saúde Pública, Ribeirão Preto, SP, Brazil.

${ }^{3}$ Universidade Lúrio, Faculdade de Ciências da Saúde, Moçambique.

${ }^{4}$ Hospital de Clínicas de Porto Alegre, Unidade de Adição Álvaro Alvim, Porto Alegre, RS, Brazil.

${ }^{5}$ Universidade de São Paulo, Escola de Enfermagem de Ribeirão Preto, Ribeirão Preto, SP, Brazil.

${ }^{6}$ Universidade Federal de São Carlos, Departamento de Enfermagem, São Carlos, SP, Brazil.

\section{ABSTRACT}

Objective: Analyzing statements of health professionals from a Street Clinic regarding care of a homeless population with tuberculosis. Method: This is a qualitative research, conducted in the central region of São Paulo at three basic health units in the period of November to December 2014. A semi-structured interview guideline was implemented for data collection and all interviews were recorded using a digital recorder. Results: Six health professionals were interviewed. According to the Discourse Analysis perspective, three discursive segments emerged: experiences on care in the streets; weaknesses inherent to the treatment process; and incentives as a means of maintaining sick people in treatment. Conclusion: Caring for a the homeless population with tuberculosis constitutes a new and challenging experience. It involves difficulties in dealing with the reality of a miserable social context, a lack and inadequacy of services, as well as care limitations for treatment and treatment dropout, which reinforces multiresistance. However, the investigated Street Clinic teams seek to expand access to health and social care services to this population.

\section{DESCRIPTORS}

Homeless Persons; Tuberculosis; Health Personnel; Public Health Nursing; Qualitative Research. 


\section{INTRODUCTION}

Tuberculosis (TB) is a serious public health problem all over the world, especially in the 22 most affected countries which account for about $80 \%$ of cases. Brazil occupies the 16th position in the absolute number of cases $^{(1-2)}$.

The most vulnerable group to TB has been the homeless population (living on the streets) as a result of poverty, lack of employment, lack of knowledge of the disease, coinfection with HIV, lack of fixed residence, low immunity, immigration and the use of psychoactive substances ${ }^{(3-7)}$. In this context, the population is $48-67$ times more likely to get sick from TB compared to the general population, thereby evidencing that this group is the most affected by the disease $^{(4,8-9)}$. Thus, they present greater need for health care, where more/better articulate services in their practices are needed to ensure comprehensive and equitable care to these individuals. Working with people living in this situation requires establishing bonds that allow for humanizing the encounters, therefore it is necessary to understand without judging, to respect and to establish boundaries ${ }^{(4)}$.

A study conducted in 71 municipalities of Brazil reported the existence of 31,992 homeless adults in 2015, and 15,905 people were also homeless in São Paulo. This finding highlights the need for health services to establish actions that provide care to the homeless population ${ }^{(2,10-12)}$.

Efforts have been made through the Street Clinic program to meet the health needs of this population, however, there are still many challenges as this is a population exposed to precarious living conditions ${ }^{(6,8)}$. The literature shows the difficulty of adherence to TB treatment and the poor access to health services regarding the health determinants of this population ${ }^{(5-10)}$. However, a lack of studies involving the homeless population and TB is perceived, especially from the statements made by professionals of the Street Clinic who work directly with this group of people who are affected by TB.

It should be noted that in Brazil, the Street Clinic was created in Salvador in 1997, designed by Professor Antonio Nery Filho. The relevance of this experience has contributed in such a way that in 2009, the Ministry of Health proposed the Street Clinic be linked to mental health policies and comprehensive care for drug users, and was adopted in 2011 with the aim of meeting the different demands and needs of this population ${ }^{(4,13)}$.

Thus, in order to contribute to scientific knowledge and in seeking to improve public policies for the homeless population, this study had the main objective of analyzing statements of health professionals from the Street Clinic regarding the care of the homeless population affected by tuberculosis.

\section{METHOD}

This is a descriptive, exploratory and qualitative research with its theoretical and methodological foundation in French Discourse Analysis (DA). DA is intended to grasp how a symbolic object produces meanings, understanding that history is manifested through language by words that reveal meanings of already made speech, being imagined or possible. Speech is not closed, it is an ongoing process of motion, it happens not as a collection of texts, but as a practice. Thus, information transmission is not prioritized, but instead a simultaneous relationship between sender and receiver, building a complex system of these subjects and of producing meanings. DA is based on three pillars of knowledge: Linguistics, Marxism and Psychoanalysis ${ }^{(14)}$

The analysis intends to understand the meanings produced by the discourse beyond what was already said, in search for clues and traces to enable capturing the opacity of the language, to produce meanings and constituting discourses through their unconscious and ideological positions. Analyzing discursively involves understanding that interpretive gestures are not closed in themselves, but may have other meanings in accordance with the position that the subject occupies discursively.

The study was conducted in the municipality of São Paulo at three Basic Health Units (UBS): Sé UBS, Republic UBS and Santa Cecilia UBS, all located in the city center. Data collection occurred from November to December 2014. Six health professionals with six or more months of experience in management and/or offering assistance to the homeless population were interviewed. Participants were selected through convenience sampling. A semi-structured script was implemented and the interview items were the following: How does the Street Clinic act regarding TB care? Which implemented strategies are useful experience? Could you talk about the benefits provided in the TB program such as the basic food package (cesta básica), snacks and transportation voucher (vale-transporte)? The interviews were recorded using a digital recorder.

The software Atlas. Ti version 7.0 was used for data organization, which helped to organize empirical data. It is noteworthy that the software does not interfere with the choice of statement segments, nor in the creation of discursive segments, it simply assisted in the organization of data selection and control which was exclusive to the researchers.

The DA reference framework was used for discursive analysis of the linguistic sequences, followed by three steps: first; linguistic surfacing for discourse, which consisted of several readings of the transcribed interviews and identifying the ideas that are part of the reference statements to form segments and discursive excerpts; second, the discourse object for forming the discourse, which consisted of discriminating discursive-linguistic and/or significant sequences that play an important role in creating meanings; and third, the discourse process for ideological training, which consisted of going back to the sequences that are the analysis objects, integrating the existing theoretical framework into the topic under study ${ }^{(14-15)}$.

The codes E1, E2, E3, E4, E5, and E6 were used to present discursive excerpts to represent the study participants. The development of this study complied with the ethical principles of research involving human subjects. The research project that originated this study was submitted to the Brazil platform, and was approved by the Research and Ethics Committee of the Federal University of São Carlos 08/12/2014 under opinion number 797.128, and 
by the Municipal Health Department of São Paulo on 10/02/2014, under opinion number 820.011.

\section{RESULTS}

Six health professionals were interviewed. Regarding the profile of the participants, they were aged between 32 and 46 years, and their experience in the Street Clinic ranged from 1 to 2 years. In relation to their profession, five were nurses and one was a psychologist.

According to the DA perspective, three discursive segments emerged: experiences on care in the streets; weaknesses inherent to the treatment process; and incentives as a means of keeping sick people in treatment. In view of the production conditions and the positions of the subjects, health professionals challenged by ideology, their speeches are inscribed in discursive formations that emphasize the current wording of the homeless population being poor, excluded and giving less attention to the problems that beset them in society, and by the difficulty of attending to them as they do not have a permanent residence.

In the experiences about care in the streets discursive segment, it is observed that from the moment professional subjects become part of the team and have to deal with a real history of which they had no previous knowledge. This encounter with the real life in the street deconstructs what had already been constructed:

(...) I thought of another kind of population, it is the kind of thing you learn by doing. I never thought that I could work with this population, I didn't even know they existed (E1).

Finding a spot for treatment has been complicated for those that are treated in the streets, as it is stated:

(...) there was a woman, and it took her a long time to get a spot, because there were spots, but no spots for women with tuberculosis (E5).

Actions in determinants of health, which include creating food and housing policies for vulnerable groups, is described as a challenge for the team:

(...) the challenge is being able to think of health policy in a broad way, but still intersectoral to ensure better living conditions, right? For food, housing... because I believe that as long as our country still has these conditions (...). Of course we will keep trying, we will keep reducing the amount of bacillary people so as not to transmit it anyway (...) the challenge of TB is to take care of tuberculosis in this context, without changing the context (E5).

One of the characteristics identified by the team of professionals from the Street Clinic is the ability to motivate for change and to respect the time of the others. These subjects found ways of building tools to promote care in insistence, persistence, strategies in comprehensible language, respecting the freedom of choice and in offering referrals which improve the living conditions of the subjects:

(...) I think persistence is what sometimes guarantees the end of the treatment because (...) that is it, I think that patients sometimes have already given up caring for themselves, right? So we cannot give up. Because if we give up, then it really is impossible (E5).
While describing their experience, the professional subject identifies the difficulties faced by the homeless population affected by $\mathrm{TB}$, and how the team continues treatment. (...) if the person can't arrange to come, which is very common because of the temporality, they don't know what day it is, they don't track time, then the community agent goes and gets them (E1).

Health professional subjects express their satisfaction in treating a fellow human being that has desires and rights, and who when perceived as such, rediscover the necessary motivation and autonomy for self-care. However, they also recognize that caring activities pose challenges, as expressed by the following statement:

For me it is a challenging experience, it's not an easy job (...) but it's a very rewarding job (E1).

There was evidence presented regarding 'weaknesses inherent in the treatment process', daily difficulties of the job, and the difficulties (inherent) in the health system itself.

In this scenario of difficulties, the following segment indicates a statement by a professional who, while blaming the patient for abandoning treatment, recognizes that there are enough health professionals in the services that can help/improve the care of the homeless population:

(...) if we were to conduct a study of all cases of abandoning treatment, we would see that the patient has a certain responsibility, yes, but both the health and the care networks are wellsupplied with professionals who could help more in this process (...) if they fought less (E6).

Compliance with certain rules, for example to attend the shelter, is required from the homeless population, and in the case such conduct is not complied with, certain restrictions are imposed, as described below by the subject:

(...) there are some requirements in the shelter, and sometimes the person gets drunk, arrives during closed hours and then they cut them off, so then we reconnect them. Look, he's an alcoholic, he had a relapse, but today he needs a spot (...) they will really cut them off, and there's no way, he will be left in the streets (...). Some shelters already have restrictions and so they don't come in, really (E2).

The process of TB treatment in the existing structure is understood as challenging and a source of distress due to the lack of institutional and social resources, as well as a lack of prior preparation of professionals for acting in this social context, since dealing with human misery is extremely difficult, as can be observed in these statements:

(...) it is a great challenge to try and take care of the health needs of this population, trying to articulate the available resources, those who have and those who don't have, creating (E5).

(...) another problem is that we start to survey, to make a lot of diagnoses, to work with their words. Gosh, I wish we had more concrete resources, right? More concrete resources to work with, more institutional supervision (E1).

\section{(...) dealing with human misery is not an easy task (E2).}

Thus, from these reports we can realize that despite having a complete team regarding human resources, fragilities 
arise from less tangible issues, or issues that do not pervade professional knowledge, which are instead based on emotional issues of each subject in the angst of facing the daily life of human misery, and the impotence of these subjects on improving or trying to (in this case) cure/treat TB. It is a context of daily sadness that is often fueled by alcohol and drugs. In this sense, the professionals seek to improve care and/or to minimize the ills of society.

Concerning the discursive segment incentives as a means of keeping sick people in treatment', we observe from the questioning how the distribution of the incentives provided for the control of tuberculosis takes place; professional subjects report that there are incentives standardized by the Municipal Secretariat of Health: basic food package (cesta básica) and transportation, and those offered by some specific UBS, i.e. showers. The "incentives" hereby mentioned are used in order to promote encouragement, arouse and stimulate interest for adherence to treatment, as well as an attempt to offer more comprehensive care. The following segments describe these incentives:

(...) there is the bond. It is through a bond that you can say to the patient: - 'Look, you need to be here.' And you want to know something that helps a lot here? Baths, because not all UBSs offer baths, but baths help a lot, this issue of bathing (E3).

Snacks are no longer available, when they were available they belped a lot, because when we had snacks it was something really nice, and adherence was higher (E2).

The medication is also considered as an incentive among the interviewees.

The incentive is basically the medication. It's the transportation voucher that is a rechargeable card, we have the basic food package, but the snacks are no longer available, it was discontinued. That's basically it. The basic food and the transportation are what we have today, basically nothing else, that is all we have as far as I know (E2).

(...) patients who complete 30 days of supervised treatment receive the basic food package. We have patients who are close to completing treatment and they do not show up because they know that from the moment they receive medical discharge, or get better/cured, they will not receive any more packages. (...) the food package for the homeless population is a great misconception, as most of them sell it and use the money for other things, or even exchange food for drugs, and that's that. (...) (E6).

What are we creating? Could it be that we are doing a disservice? That perhaps we are stimulating this bacteria to get stronger? And creating a resistance? (E5).

\section{DISCUSSION}

Health professionals experience the reality of homeless patients in their activities. The characteristics of life on the streets, although imaginatively known by health professionals, produce significances that lead them to understand this homeless subject inserted and marked in a sociohistorical situation which is invisible to the eyes of many. The linguistic discursive remark "thought of another type of population", suggests an imaginary incongruity between the current meanings of the street population the actual story experienced by them. The same linguistic remarks indirectly produce meanings revealing the fragility of health professionals in dealing with this population group who are living in precariousness, exclusion and social invisibility ${ }^{(6,9,16)}$.

In the discursive sequence "I never imagined (...) I didn't even know they existed", takes into account the production conditions, the subject's position presents invisibility, objectification and marginalization of this group under conditions that hinder recognizing their rights and for them to receive proper treatment for their health needs $s^{(6)}$.

The significance of "it took a long time" produces meanings of not only the difficulty of this population to get access to health services, but also the delay of their diagnosis and treatment, allowing the disease to spread among the other people who live together, as well as facilitating aggravation of the disease ${ }^{(16)}$. The discursive sequence "there were no spots for women with tuberculosis" instigates reflection on stigmatization and labeling of sick individuals as women and worse, as a homeless women with TB. In this context, the complexity of homelessness for women imposes expanding the very concept of care, incorporating interdisciplinary, intersectoral and gender issues in its essence. The situation of living in the streets opens the door to the misery of the human condition added to the affliction of $\mathrm{TB}$, which is a complex issue for both health professionals and managers. State and civil society health actions for this population often occur under a welfare perspective or hygienic policies. Acting in this challenging environment may not often be a professional choice, but an event. The challenge of talking about health amid the drug scene and encountering life stories in distressing contexts are events that require a unique exercise marked by the construction and deconstruction of values ${ }^{(17)}$.

The position of the subject in stating the discursive language remarks "better conditions; food; housing" are inscribed in discursive formations that link TB to precarious health and life conditions of those sickened by TB experience ${ }^{(7)}$. It is also important to note that the subject, by stating such linguistic remarks, is questioned by interdiscourse, since the words are not from the subject witness, they were spoken somewhere else at another moment and they are registered in several policy documents on TB control of the World Health Organization and of the TB control program ${ }^{(1)}$.

Thus, among the peculiarities of the work described by the respondents, there is the need and importance of professional teams having the profile for establishing bonds or if they are willing to do it. The bond between TB patient and the professional and health services is directly related to the continuity of care $^{(4)}$ and success of the treatment.

In the search for solutions to the problem of TB in the homeless population, professional subjects believe that action on the social determinants understood as better social conditions such as housing, education, recreation, sanitation, employment and change of lifestyle can be facilitators for reducing the disease in this group ${ }^{(18-19)}$. The linguistic remark 'challenge' indicates the need for change and new 
perspectives of health care, such as intervention in all of the health production chain: health promotion, disease prevention, surveillance and rehabilitation, in addition to medical care and medication ${ }^{(20)}$. The TB issue is often seen as a sum of sick individuals, and such a vision reduces the individual to the disease. However, TB control primarily requires an understanding of sick subjects as individuals beyond the biological sphere, but also the social and psychological spheres, which drives action on these spheres in a coordinated way to reduce the incidence and prevalence of the disease ${ }^{(21)}$.

Although the cure involves the appropriate use of effective regimens for disease control by the patient, the solution also requires programs that seek adequate quality of life ${ }^{(22)}$. Quality of life is understood as the person's perception of their position in life in the context in which they are and in the system of values in which they experience, considering their expectations, goals and concerns ${ }^{(23)}$. Thus, guaranteeing expanded service to this population becomes a priority, and for that, inter-agency coordination between workers from different areas of knowledge who deal with the homeless population is essential, especially among health teams and social care.

The discursive sequence "persistence guarantees (...) the end of treatment" produces the sense that health professionals exert power over the sick individual to keep them in treatment and disciplined. The action of community workers in pursuing sick individuals to keep them in treatment reinforces the idea that there is a disciplinary control that is exercised over sick individuals without considering their particularities, especially their basic needs.

It is noted that the discursive sequences "it is a challenging experience; it is a rewarding job" indicate that care has been constituted as an experience that, on the one hand, challenges the health workers, but on the other is regarded as rewarding. Thus, it is noted that the statements 'challenging and rewarding' produce consistent meanings in which professionals enter the social reality of the excluded with serious difficulties in treatment adherence and for being on the streets. On the other hand, when they are able to help these sick individuals recover from the disease, it produces a significance of saving a fellow human act understood as rewarding and gratifying for professional subjects.

Regarding weaknesses inherent to the treatment process, the statements on the subjects' positions report difficulties that professionals and the homeless population experience. These statements produce meanings of needing co-responsibility in the care process, as the commitment to health must be shared by both the patient, the professional and the services that attend them. Care provision should be carried out collectively and intersectorally as a team, including providing resources and incentives as a measure to ensure the success of the practices by health professionals; in contrast, their absence weakens these actions. The meaning 'fight' unveils the need to work in favor of the sick person, and not waste time with unnecessary circumstances. On the other hand, the same meaning produces significance that the fight is directly linked to a lack of partnership in intersectoral and personal relationships, resulting in difficulties of working together and the need to make compromises in order to meet common ground. Thus, the necessity of working as a team in a coordinated manner becomes essential to ensure successful treatment ${ }^{(24)}$. However, it is important to say that the team needs both material and human management support.

The linguistic-discursive marks "arriving drunk; during closed hours" highlights the behavior of homeless patient subjects who don't follow the rules of the shelters. The rigorousness of the discipline of these institutions establishes an authoritarian relationship in which the patient subject loses autonomy and does not participate in the decisionmaking process. The action of excluding the patient subject brings out a meaning of avoiding closeness and contact with them, stigmatizing them as deviant and therefore undesirable in that place ${ }^{(25-26)}$. In this context, the streets appear as a welcoming place, as there are no rules nor requirements for being in it, the streets do not restrict access, in contrast, they are available to whomever wants them or those obliged to make it as their address ${ }^{(7)}$.

The structure of services for the healthcare of the homeless population appears to be insufficient to meet the singularities of this population, because the teams need to make use of personal and direct work of the networks and formal systems of available public institutions which are rarely used. The significance of 'try' remark indicates that the structure is not available. It is not given. They work with what they have, with what is possible, due to a shortage of resources. It is important to make clear that even with an adequate number of professionals (as we have seen in the statements), there are weaknesses in relation to the comprehensiveness of the health services, and there is a lack of intersectoral communication; situations that, if addressed, could strengthen actions aimed towards the homeless population.

It is observed that many times what is said emerges from the unsaid; that other troubles are present in everyday life, and there is a lack of institutional support for their own care. The linguistic discursive remarks "caring for the needs; making use of the available resources; working with their words; Gosh!" suggest indignation and vindication, indicating a lack of effective resources for the job. The statements echo as regretful speech, a call for help and support. Understanding resilience as the ability of a person or team to overcome adversity and to use it for their own personal development or development of the team ${ }^{(27)}$, and a need to implement care strategies with these health professionals providing emotional support and resilience building with the team is necessary. The use of the term resilience in the health area is indicated to understand an interactive phenomenon, based on findings related to favorable outcomes in critical and adverse situations ${ }^{(28)}$.

One hand, the linguistic-discursive remarks "(...) buman misery; It is not (...) easy”, suggests emotional pain of the health professional in experiencing this reality that exposes the patient to undergo a systemic vulnerability that somehow produces meanings of impotence for health professionals; however, on the other hand, “(...) I wish we 
had more concrete resources (...)" produces a significance that dealing with the homeless patient requires the availability of material resources. The social context of homeless TB patient subjects not only requires the intervention of medical staff, but also of other social services that can minimize their basic needs ${ }^{(16)}$.

Considering the direct symbolic relationship of TB with poverty, and while there are no effective public policies to ensure human rights to housing, food, health, employment, education and leisure, thereby hindering the hope and prospects that TB will be eradicated. Thus, the personal care structure affected by TB is beyond the use of multichemical therapies to eliminate $\mathrm{TB}$ and promote healing, and requires investment in public policies that provide social justice.

In this direction, and in relation to 'incentives', we can observe that the positions of professional subjects are affected by the natural feeling (ideology) that the homeless population is always in need; they understand that bathing, transportation vouchers and food packages as rewards for adherence and continuity to treatment, and that such "rewards" positively contribute to the bond between professionals and health services. Establishing bonds is related to proximity of the professional to the individual, built by providing not only biological aspects, but also affective and intimate ones ${ }^{(29)}$.

The lack of such incentives has been identified as challenges by professional subjects, as it may constitute an obstacle to adherence to treatment, although these same incentives, for example the distribution of food packages, are targets for reflection and can produce outcomes such as their sale in exchange for money.

Similarly, the discursive sequence "(..) basically nothing else, that is that" suggests that the incentives available for encouraging treatment do not meet the actual needs of the population, considering that the homeless population have nowhere to cook the food from the basic food package, nor the need to use the transportation vouchers given their profile of traveling long distances on foot, daily. Also, the incentive that best met the needs of the subject is no longer available, "the snacks are no longer available, it was discontinued". The snack consisted of a kit containing a milk drink, a cereal bar and a small individually wrapped cake, served in the morning after supervised administration of medication.

The discursive sequence 'it is a great misconception' reveals a metaphor, a mistake, producing the meaning that the practice of delivering available benefits was not effective, it does not produce the expected results.

Due to the irregularity in the supply of the anticipated benefits, the teams felt insecure to disclose this information, as this weakens the bond. Thus, it is common that the benefits/incentives are only delivered when the patients arrive. Irregular administration of medication and abandoning treatment have been one of the concerns of professionals working in the Street Clinic, considering that reinfection is inseparably linked to multi-resistance. According to the World Health Organization, by definition multidrug-resistant TB is resistance to ionized drugs + rifampicin, confirmed by a sputum culture with a drug sensitivity test, and it has a direct connection to abandoning treatment ${ }^{(11,30)}$.
Reflective discourse in which discursive sequences are ended by question marks “(...) creating? (...) disservice? (...) strengthen? (...) resistance?" suggests concerns about the culpability of health services in treating the disease, and by repeatedly using the expression we, the professional subject assumes the responsibility themselves for the bacterial multidrug resistance. In this sense, co-responsibility is discourse of the programs, the professional subject is affected by the interdiscourse, and reproduces the standardized/official speech. However, absence/deletion of reflection on the material conditions for care development is noted. This absence can, in a way, indicate the little importance given to the lack of material that is mentioned in various speech segments.

We emphasize that the incentives used as resources for adherence to TB treatment should not be standardized, but the specific and real needs of the population attended must be considered above all through listening to the Street Clinic teams. The reflection remains on what are the most appropriate delivery strategies to stimulate adhesion, treatment and cure, without the use of these incentives as a strategy for maintaining the disease or as financial means for acquiring psychoactive substances.

\section{CONCLUSION}

Considering the claims of the theoretical and methodological framework of DA, this study analyzed the speeches of professionals from Street Clinic teams in caring for people with TB. In this context, understanding the speech from the perspective of DA is achieved by understanding what is produced by an encounter between stakeholders in a given context and time; therefore, the act of interpreting the results cannot be understood as exclusive, nor even as finished.

From the remarks of the health professionals, it can be understood that caring for homeless subjects with TB is a new experience that falls outside the current collective imagination. In dealing with the reality of this population, the professionals indicated in their speeches the current meaning for the situation for patients in street, being understood as miserable and difficult to attend.

Health professionals from the Street Clinic teams reported difficulties in performing within the context of misery, the willingness to act in non-scheduled situations; the prejudice from both the patients and health professionals; stigmatization of the population attended and their invisibility as rightful citizens; the need to facilitate access to health and social care services, ensuring integrated and personalized attention.

In this investigation, it is noted that the dimension of the disease is different for each subject, so it has a direct influence on adhesion or not to treatment; understanding this process is fundamental for care that allows healing and works within a network. The inability to change the context of poverty in which patient subjects live and the deficiency and/or lack of institutional support for patients and professionals in relation to TB control generate feelings of helplessness and demotivation among professionals.

We also point out that the performance of Street Clinic teams significantly contributes to the access of this 
population to health services and increases early detection, treatment, monitoring and curing of TB patients.

As a limitation of this study, we can consider the use of the qualitative methodological approach which does not allow us to generalize the results. The meanings produced from the professional discourses are not concrete, and they may turn out to be different if analyzed by another analyst or if another theoretical framework is used.

\section{RESUMO}

Objetivo: Analisar os discursos dos profissionais de saúde do Consultório na Rua em relação ao cuidado à pessoa em situação de rua com tuberculose. Método: Trata-se de uma pesquisa qualitativa, realizada na região central do município de São Paulo, em três Unidades Básicas de Saúde, no período de novembro a dezembro de 2014. Utilizou-se de um roteiro de entrevista semiestruturada para a coleta de dados e todas as entrevistas foram gravadas com recurso a um gravador digital. Resultados: Foram entrevistados seis profissionais de saúde. Segundo a perspectiva da Análise de Discurso, emergiram três blocos discursivos: experiência sobre o cuidar na rua; fragilidades inerentes ao processo de tratamento e incentivos como meio para a permanência do sujeito doente no tratamento. Conclusão: Cuidar da pessoa com tuberculose e em situação de rua constitui uma experiência nova e desafiadora, implica dificuldades em lidar com a realidade de um contexto social miserável, falta e inadequação de serviços, bem como limitações do cuidado para a cura e abandono do tratamento, podendo reforçar a multirresistência. Contudo, as equipes de Consultório na Rua investigadas buscam ampliar o acesso aos serviços de saúde e assistência social a essa população.

\section{DESCRITORES}

Pessoas em Situação de Rua; Tuberculose; Pessoal de Saúde; Enfermagem em Saúde Pública; Pesquisa Qualitativa.

\section{RESUMEN}

Objetivo: Analizar los discursos de los profesionales sanitarios del Consultorio en la Calle con respecto al cuidado a la persona en situación de calle con tuberculosis. Método: Se trata de una investigación cualitativa, realizada en la región central del municipio de São Paulo, en tres Unidades Básicas de Salud, en el período de noviembre a diciembre de 2014. Se utilizó un guión de entrevista semiestructura para la recolección de datos y todas las entrevistas fueron grabadas con recurso a un grabador digital. Resultados: Fueron entrevistados seis profesionales sanitarios. Según la perspectiva del Análisis del Discurso, emergieron tres bloques discursivos: experiencia sobre el cuidar en la calle; debilidades inherentes al proceso de tratamiento e incentivos como medio para la permanencia del sujeto enfermo en el tratamiento. Conclusión: Cuidar a la persona con tuberculosis y en situación de calle constituye una experiencia nueva y desafiadora, implica dificultades en manejar la realidad de un contexto social miserable, falta e inadecuación de servicios, así como limitaciones del cuidado para la curación y abandono del tratamiento, pudiendo reforzar la multiresistencia. Sin embargo, los equipos de Consultorio en la Calle investigados tratan de ampliar el acceso a los servicios sanitarios y asistencia social a esa población.

\section{DESCRIPTORES}

Personas sin Hogar; Tuberculosis; Personal de Salud; Enfermería en Salud Pública; Investigación Cualitativa.

\section{REFERENCES}

1. World Health Organization. Global Tuberculosis Report 2015. Geneva: WHO; 2015.

2. Boletim Epidemiológico. Detectar, tratar e curar: desafios e estratégias brasileiras frente à tuberculose. Brasília: Ministério da Saúde, Secretaria de Vigilância em Saúde [Internet]. 2015 [citado 2016 mar. 20];46(9). Disponível em: http://portalsaude.saude.gov.br/images/ pdf/2015/marco/27/2015-007---BE-Tuberculose---para-substitui----o-no-site.pdf

3. Boletim Epidemiológico. O controle da tuberculose no Brasil: avanços, inovações e desafios. Brasília: Ministério da Saúde, Secretaria de Vigilância em Saúde [Internet]. 2014 [citado 2016 mar. 19];45(2). Disponível em: http://portalsaude.saude.gov.br/images/pdf/2014/ maio/29/BE-2014-45--2--tb.pdf

4. Brasil. Ministério da Saúde. Manual sobre o cuidado à saúde junto à população em situação de rua. Brasília: MS; 2012.

5. Jagodziński J, Zielonka TM, Błachnio M. Socio-economic status and duration of TB symptoms in males treated at the Mazovian Treatment Centre of Tuberculosis and Lung Diseases in Otwock. Pneumonol Alergol Pol. 2012;80(6):533-40.

6. Souza VCA, Pereira AR, Goutijo DT. A experiência no serviço de Consultório de Rua na perspectiva dos profissionais: contribuições para atenção ao usuario de álcool e outras drogas. Cad Tera Ocup. 2014;22 Supl.:37-47.

7. Pinheiro RS, Oliveira GP, Oliveira EXG, Melo ECP, Coeli CM, Carvalho MS: Determinates sociais e autorelato de tuberculose nas regiões metropolitanas conforme a pesquisa nacional por amostra de domicílios. Rev Panam Salud Publica. 2013;34(6)446-51.

8. Feske ML, Teeter LD, Musser JM, Graviss AE. Counting the homeless: a previously incalculable tuberculosis risk and its social determinants. Am J Public Health. 2013;103(5):839-44.

9. Aguiar MM, Ariart JAB. Significados e práticas de saúde e doença entre a população de rua em Bahia, Brasil. Cad Saúde Pública. 2012;28(1):115-24.

10. Getahum H, Matteelli A, Abubakar I, Aziz MA, Baddeley A, Barreira D, et al. Management of latent Mycobecterium tuberculosis infection: WHO guidelines for low tuberculosis burden countries. Eur Respir. 2015;(46):1563-76.

11. Boletim Epidemiológico. Especial Tuberculose. Brasília: Ministério da Saúde, Secretaria de Vigilância em Saúde [Internet]. 2012 [citado 2016 mar. 19];43. Disponível em: http://portalsaude.saude.gov.br/images/pdf/2014/julho/23/BE-2012-43-Mar--O---Especial-Tuberculose.pdf

12. Fundação Instituto de Pesquisas Econômicas. Censo dos moradores de rua da cidade de São Paulo. São Paulo: Secretaria de Assistência Social/FIPE; 2015. 
13. Jorge JS, Corradi-Webster CMC. Consultório de Rua: contribuições e desafios de uma prática em construção. Saúde Transform Soc. 2012;3(1):39-48.

14. Orlandi EP. Análise de discurso: princípio e procedimentos. 12ª ed. Campinas: Pontes; 2015.

15. Courtine JJ. Análise do discurso: o discurso comunista endereçado aos cristãos. São Carlos: EduFscar; 2009.

16. Cheng JM, Hiscoe L, Pollock SL, Hasselback P, Gendy JL, Parker. A Clonal outbreak of tuberculosis in homeless population the interior of British Columbia, Canada, 2008-2015. Epidemol Infect. 2015;143(15):3220-6.

17. Londero MFP, Ceccim RB, Bilibio LFS. Consultório de/na rua: desafio para um cuidado em verso na saúde. Interface Comun Saúde Educ. 2014;18(49):251-60.

18. Awalli J. Poverty and health care demand in Kenya. BMC Health Serv Res. 2014;14:560.

19. Maxwell AE, Young S. Crespi CM, Veja RR Caetano RT, Bastani R. Social determinants of health in the Mixtec and Zapotec Community, California. Int J Equity Health. 2015;14:16.

20. Malta DC, Merhy EE. O percurso de linha do cuidado sob a perspectiva das doenças crônicas não transmissível. Interface Comun Saúde Edc. 2010;14(34):593-605.

21. Shiotani R, Hennin K. Socio-cultural influences on adherence to tuberculosis treatment in rural Indua. Global Public Health. 2014;9(10):1239-51.

22. Ruffino-Netto A. Tuberculose: a calamidade negligenciada. Rev Soc Bras Med Trop. 2002;35(1):51-8.

23. Oliveira FBM, Moura MEB, Araújo TME, Andrade EIMLR. Quality of life and associated factors in people living with HIV/AIDS. Acta Paul Enferm. 2015; 28(6):510-6.

24. Viegas SMF, Penna CMM. A construção da integralidade no trabalho cotidiano de equipe Saúde de Família. Anna Nery Rev Enferm. 2013;17(1):133-41.

25. Andrade VC, Oliveira FR, Rojas AC. O estudo da resiliencia dos residentes do Programa de Residência Multiprofissional em Saúde da Família. Bol Instituto Saúde. 2014;15(2):56-63.

26. Souza KMJ, Assolini, FEP, Sá LD, Queiroga RPF, Surniche CA, Palha, PF. Discursos sobre a tuberculose: estigmas e consequências para o sujeito adoecido. Rev Enferm UERJ. 2015;23(4):475-80.

27. Souza KMJ, Villa ICS, Assolini FEP, Beraldo AA, França UM, Protti ST, et al. Atraso no diagnóstico na tuberculose em sistema prisional: a experiência do doente apenado. Texto Contexto Enferm. 2012;21(1):17-25.

28. Rutter M. Annual research review: resilience: clinical implications. J Child Psychol Psychiatry. 2013;54(4):474-87.

29. Brunello MEF, Cerqueira DF, Pinto IC, Arcêncio RA, Gonzales RIC, Villa TCS, et al. Interaction between patient and health care professionals in the management of tuberculosis. Acta Paul Enferm. 2009;22(2):176-82.

30. Santos LAR, Fukasava S, Galesi VMN. Alguns aspectos epidemiológicos do controle da tuberculose no estado de São Paulo. Bol Epidemiol [Internet]. 2012 [citado 2016 mar. 19];2(11):177-88. Disponível em: http://portal.saude.sp.gov.br/resources/cve-centro-de-vigilanciaepidemiologica/publicacoes/e-becve/bol1112.pdf 